\title{
The Bible in the Syriac Tradition
}

\author{
Third Edition
}

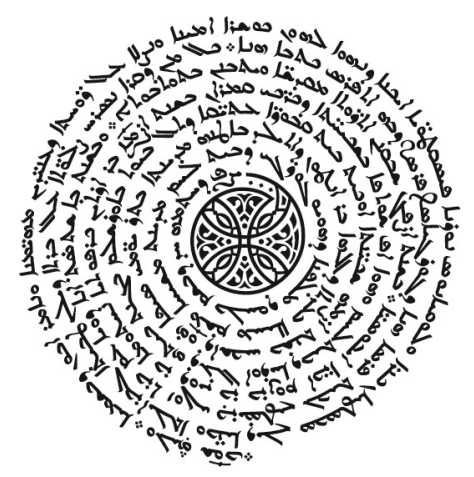




\section{Gorgias Handbooks}

52

Gorgias Handbooks provides students and scholars with reference books, textbooks and introductions to different topics or fields of study. In this series, Gorgias welcomes books that are able to communicate information, ideas and concepts effectively and concisely, with useful reference bibliographies for further study. 


\title{
The Bible in the Syriac Tradition
}

\author{
Third Edition
}

Sebastian P. Brock

\author{
Gorgias \\ JPREss \\ 2020
}


Gorgias Press LLC, 954 River Road, Piscataway, NJ, 08854, USA

www.gorgiaspress.com

Copyright (C) 2020 by Gorgias Press LLC

All rights reserved under International and Pan-American Copyright Conventions. No part of this publication may be reproduced, stored in a retrieval system or transmitted in any form or by any means, electronic, mechanical, photocopying, recording, scanning or otherwise without the prior written permission of Gorgias Press LLC.

2020

$\downarrow$

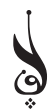

ISBN 978-1-4632-4233-6

ISSN 1935-6838

First published by Gorgias Press (Second Revised Edition) in 2006.

\section{Library of Congress Cataloging-in-Publication Data}

A Cataloging-in-Publication Record is available
from the Library of Congress.

Printed in the United States of America 